\section{Welfarism and extra-welfarism: a critical overview}

\author{
Welfarism e extra-welfarism: uma visão crítica \\ Welfarism y extra-welfarism: una visión crítica
}

Brayan Viegas Seixas 1

doi: 10.1590/0102-311X00014317

\begin{abstract}
Rules and principles for guiding decision-making in the health care sector have been debated for decades. Here, we present a critical appraisal of the two most important paradigms in this respect: welfarism and extra-welfarism. While the former deals with the maximization of the overall sum of individual utilities as its primary outcome, the latter has been focusing on the maximization of the overall health status. We argue that welfarism has three main problems: (1) its central idea of overall sum of individual utilities does not capture societal values decisively relevant in the context of health; (2) the use of the Potential Pareto Improvement brings an unresolvable separation between efficiency and equity; and (3) individual utility may not be a good measure in the health sector, given that individuals might value things that diminish their overall health. In turn, the extra-welfarist approach is criticized regarding four main limitations: (1) the advocated expansion of the evaluative space, moving from utility to health, may have represented in reality a narrowing of it; (2) it operates using non-explicit considerations of equity; (3) it still holds the issue of "inability to desire" of unprivileged people being considered the best judges of weighing the criteria used to building the health measures; and (4) there is controversial empirical evidence about society members'values that support its assumptions. Overall, both paradigms show significant weaknesses, but the debate has still been within the realm of welfare economics, and even the new approaches to resource allocation in health care systems appear to be unable to escape from these boundaries.
\end{abstract}

Resource Allocation; Health Care Rationing; Health Economics; Decision Making

\author{
Correspondence \\ B. V. Seixas \\ University of British Columbia. \\ 2206 E Mall, Vancouver, British Columbia - V6T 1Z9, Canada. \\ brayan.seixas@alumni.ubc.ca \\ 1 University of British Columbia, Vancouver, Canada.
}




\section{Introduction}

The study of resource allocation represents the foundational pillar of the discipline of economics and it is undeniably one of the main concerns regarding any health care system. Rules for decision-making and principles to base economic evaluation are central in this discussion and have a tremendous impact on the production and distribution of welfare. Within the realm of health economics, two major concepts of fundamental importance for this discussion are efficiency and equity.

Efficiency is a broad term that has three major dimensions, usually approached in the neoclassical economics field. The first one is the idea of technical efficiency, which basically addresses the question of efficiency in the production of goods (productivity), i.e., the ways of achieving the highest possible outputs given a specified amount of inputs. The second conception of efficiency, in turn, refers to the comparison amongst the technically efficient methods, and assumes that the one with the lowest cost of production is the most efficient. Thus, this notion is commonly referred to as cost-effectiveness efficiency. And, lastly, the third dimension is allocative efficiency, which deals with the distribution of goods in relation to the way individuals value and judge these goods. In other words, allocative efficiency considers people's preferences, or, to lapse it into economic jargon, the utility derived from the goods.

The notion of utility is absolutely central in the field of economics. Utility relates precisely to the idea of individual satisfaction derived from a given service or good. It works as a heuristic tool and can be defined, according to Hargreaves Heap et al. (1992, apud Coast 1, p. 787), as "a numerical representation of preferences". Having its roots in the philosophical tradition of utilitarianism, which has as its fundamental premises the maximization of pleasure and minimization of pain, utility may as well be understood, according to Blaug (1996, apud Coast 1, p. 787), as "the quantity that an individual should maximize or that society should help him to maximize". This manner of comprehending economics and its purposes is broadly referred to as welfarism.

In a welfarist world, the main principle used is the Potential Pareto Improvement: the idea that the resources should be allocated in a way to maximize the overall sum of individual utilities. This idea considers, however, that the gains of the winners are sufficiently large to compensate the losers for their losses and be still better off. Within this paradigm, health services would be seen simply as any other good produced within the economy and its consumption would derive its utility. The utility, consequently, is not health itself, but the values attributed by the individuals to the health care services. Thus, the maximization of efficiency in the health care system would be achieved by the maximization of these individual utilities derived from the use of services.

A subsequent approach that appeared later addressing the issue of allocative efficiency in health care is extra-welfarism. This other paradigm operated a shift of the evaluative space, moving from the maximization of the utility to the maximization of health. In this respect, the word extra meant exactly to provide this expansion from the sole concept of utility to health itself. The underlying assumption of this stance is that all individuals present similar utilities for the same health interventions and/or health states. Extra-welfarist economists, then, assume that the role of health services is to increase the overall health of society, and they use it to base the cost-effectiveness analysis for deciding which investments should be chosen. Thus, an innumerable set of indicators of health have been used to analyse which practices and technologies lead to the maximization of overall health, with a predominant emphasis on QALYs (quality adjusted-life years), a combination of years and quality of life gained through an intervention.

The other important concept used to appraise welfare in the health care sector is equity, given that health is dealt as a human right, unquestionably an essential piece of human dignity. However, seemingly, equity has not been adequately studied by health economists, as it can be seen, for instance, in the first 25 years of the Journal of Health Economics (a journal definitely crucial to establishing health economics as a field of research), in which equity represents only $2.5 \%$ of the cumulative total keywords 2.

In this study, we aim to elaborate some critiques pertinent to these two paradigms, welfarism and extra-welfarism. The reflections here presented are valuable to the design and implementation of decision-making practices with strong scientific bases. Overall, through our discussion on welfare health economics, we are inevitably dealing with other significant critical appraisal of this market. 
Apart from the uniqueness of the health care market typically considered in textbooks (such as asymmetry of information, supplier-induced demand, demand for health care as a derived demand and so on), the social and communitarian values that individuals carry with them regarding health and human life lead them to behave in ways that cannot be appropriately and/or thoroughly understood by an individualistic perspective of behavioural sciences.

This article is outlined in the following way: in Criticism on the Welfarist Approach, we present what we consider to be the three main critiques to the welfarist paradigm; in Criticism on the Extra-Welfarist Approach, after a brief discussion on the precise distinction here used between welfarism and extrawelfarism, we argue that there are four significant weaknesses in the extra-welfarist approach; then, finally, to sum up the discussion, we elaborate a few other considerations.

\section{Criticism on the welfarist approach}

\section{Societal values are not necessarily represented in the notion of overall sum of individual utilities}

At least since Durkheim, one of the founders of Sociology, social scientists have been aware of the theoretical standpoint that society is not same thing as the simple gathering of the individuals that compose it. Durkheim postulated that there are many social facts, such as law, morality, statuses, roles, etc., that make the whole of society. Along these lines, collective representations, i.e., social values, understandings and notions, are not the mere creation of individuals' intentions or the overall sum of individuals' representations. Social facts are phenomena of society and are engendered within the social environment. In other words, collective representations cannot be studied by the simple sum of individual stances 3 .

In this sense, the concept of utility may serve quite well for the consideration of markets, where there is a predominance of more individualistic characteristics at pursuing their own interests over the rest. In the health care system, however, there are several social values that lead individuals not to behave as predicted by the classical utilitarian and individualistic assumptions of microeconomics. People, for instance, may value more the health of certain groups and may be more interested in equity than efficiency. As Mooney 4 arguments in his book Challenging Health Economics, there are humanitarian, caring, and compassionate positions that individuals consider about the delivery of health care. It means more than the simplistic acknowledgement of externalities on these judgments, such as the inclusion of interpersonal effects in the function of individual utility. These values are embodied by the individuals and may be reinforced or not by other social facts 4 .

\section{Classical welfarist economics presumes an unresolved(able) separation between equity and efficiency}

The classical Pareto principle states that society should reallocate resources, maximizing the overall utility in a way that makes at least one person better off without making someone else worse off. Due to the two major limitations of this thinking, i.e., the impossibility of determining a single best allocation and the empirical remark that virtually no actual rearrangement of resources produces a benefit to someone without inevitably hurting someone else, many economists in the first half of the 20th century sought to develop a more sophisticated theoretical foundation for the idea of utility maximization within Paretian terms. Then, the two economists who established a new paradigm for Paretian improvement, Kaldor 5 and Hicks 6 , developed the idea that it is possible to achieve allocative efficiency if the gains of the winners are sufficiently large so that they can compensate the losers for their losses and still be better off.

Under these new terms, then, Kaldor 5 elaborated that the process of achieving overall efficiency should happen in two steps. Firstly, the economist should be concerned only with the economic decisions about resource reallocation aiming the maximization of utility. Within this paradigm, the social indifference curve is a downward straight line of slope -1 , as we can see in Figure 1. The optimal point is the tangency between the grand utility possibilities frontier and the social indifference curve (point a). 


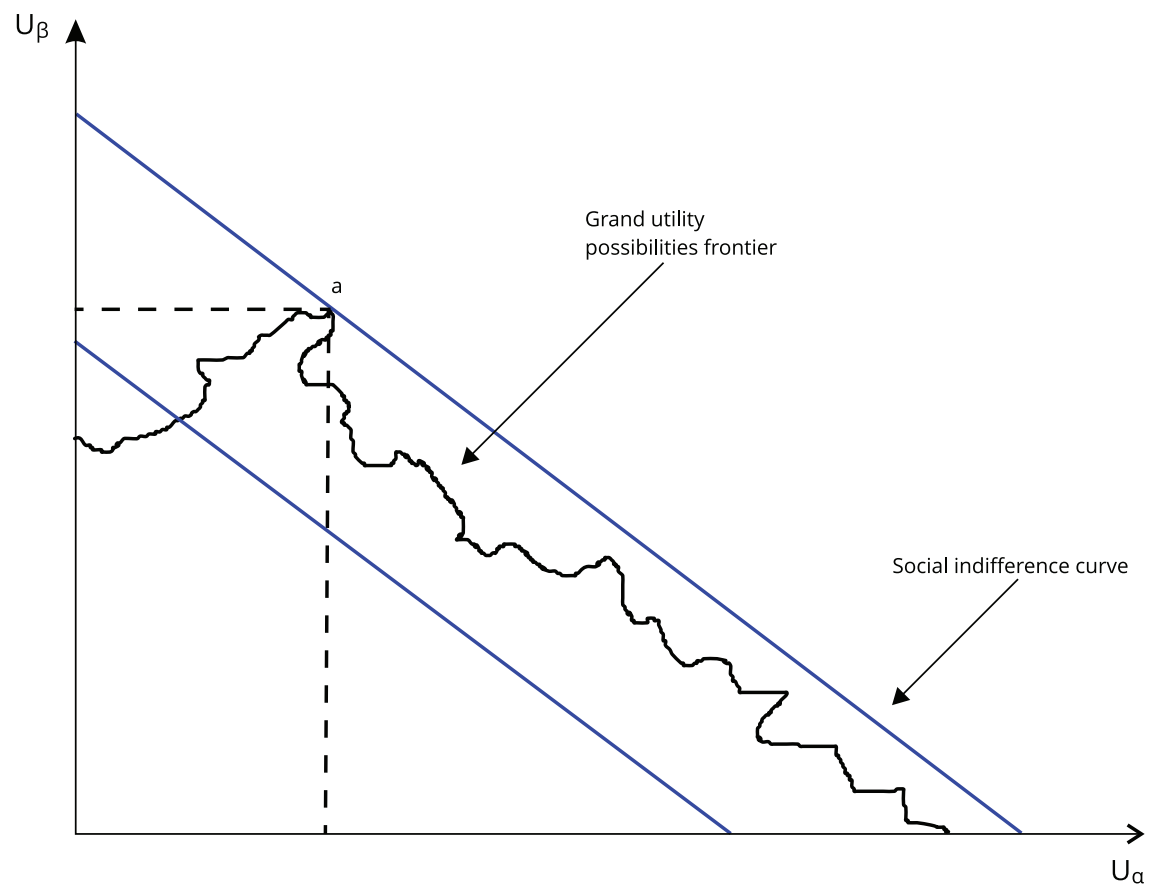

In this first moment, it does not matter whether individual or group $\beta$ derive much more utility than individual or group $\alpha$.

In the subsequent step, then, the fairness of the distribution of resources should be a concern for politicians and policy makers. As Blaug (1996, apud Coast 1, p. 591) precisely highlights, this approach "offers no opinion, however, on whether such compensation payment should be made, that is, it stops at the point at which it has enumerated the gains and losses to various individuals and ventures no judgement on how these gains and losses should be distributed".

Finally, how do we compensate the "losses" within the context of the health care system? The question of redistribution within the realm of health services poses two main difficulties. First, this process establishes a trade-off with the efficiency goal, for redistributing leads to a loss of overall welfare. Second, it gives rise to highly debatable issues, such as the valuing of life, the possible differential values attributed to the lives of different individuals, and many other controversial ethical issues.

\section{The use of individual utility to maximize social welfare in the health care system} may lead to suboptimal or negative impacts on health outcomes

When individual utility is used as the maximand in the health care market, it is not unreasonable to think that individuals may find their best interests in interventions that exert a negative impact in their health. Rice (1998, apud Birch \& Donaldson 7, p. 1125), for instance, defends that "individuals need to be protected from their own foolishness". At first glance, this seems an arrogant position of someone who presumably knows better what is best for other individuals and, henceforth, is aware that health policies may need to go against people's best interests. Nonetheless, this paternalistic position may be actually necessary if the society cares more about their overall health rather than individual utilities. An illustrative example is the anti-vaccination movement. Its partisans prefer the non-vaccination of 
them and their children, even though that attitude puts in risk the entire population. Another example is the practice of quarantine in certain outbreaks of infectious disease. Individuals may not value quarantine and, thus, the act of not isolating infected persons may lead to enormous negative impacts for everyone. Society, therefore, does not always maximize the welfare in the health sector by the consideration of individuals' utilities. The lack of appropriate information and or even the legitimate right to stubbornness constitute real problems for welfarist approaches in the health sector.

In several cases, though, individuals may not necessarily act "foolishly" or against their own health status, but they may simply present an "inability to desire", as worded by Amartya Sen. The rationale argued by Sen is that the people's preferences are not inherent manifestations of individual selves. Yet, our preferences are conditioned by the experiences and expectations of the social environment and social pathway we have been raised and lived in. Thus, those people in the lower socioeconomic ranks of society have truncated expectations, circumscribed by a lifetime (or generations) of limited possibilities. Their horizon of well-being is likely narrowed by the embodiment of the disadvantaged social position. Consequently, a welfarist approach may yield an unfair distribution of resources against unprivileged people, and this is even more significant in societies with greater socioeconomic inequalities ${ }^{8}$.

\section{Criticism on the extra-welfarist approach}

Before we move to the examination of the weaknesses and limitations of the extra-welfarist approach in the economic evaluation and decision-making within the health care system, it seems wise to bring up some thoughts on the historical "transition" between these two paradigms and their distinctions. Firstly, it is important to remark that there is no consensual idea on the precise definition of extrawelfarism and its deviations from welfarism 7,9.

Secondly, it is interesting to observe that, as Coast 1 highlights, the theoretical foundations of extra-welfarism were not developed prior to their implementation, given that practices on economic evaluation of health services that can be deemed as extra-welfarist are reported in the literature since the late 1960s. On the contrary, the theoretical structures of this paradigm were only explicitly elaborated in the late 1980s by some health researchers, with particular prominence of the British economist Anthony Culyer 10.

His criticism on the application of neoclassical welfare economics in the health sector relied on two key points: (1) social welfare is not independent of non-utility facets of resources reallocations and (2) individual utilities are not independent of non-good aspects of individuals, as assumed by the welfarist model. Then, adopting the notion developed by Amartya Sen of capabilities, Culyer 10 proposed a theoretical framework that would go beyond the focus of individual utilities, contending the need of acknowledging other aspects in the pursuit of social welfare. Hence, the rise of extrawelfarism in health economics represents an attempt of operating a shift in the evaluative space within economic evaluation and decision-making towards a broader spectrum that could encompass capabilities and other aspects, including health.

\section{The alleged expansion of the evaluative space might actually have narrowed it}

The addition of the word "extra" meant precisely to cover this expansion of the evaluative space. Yet, as Birch \& Donaldson 7 (p. 1122) remark: "although EW (extra-welfarism) explicitly proscribes individual utilities as a measure of social welfare, it does not provide a clear specification of what does determine social welfare". Even though the passage from welfarism to extra-welfarism has been defended in theory as a manner to go away from a narrow focus on utility to an inclusion of other characteristics important to individuals and social welfare, what has been seen, on the contrary, in the practices deemed as extrawelfarist in health economics, is an almost exclusive focus on health. As Coast 1 sleekly notes, there is a disjoint between the theoretical expositions of extra-welfarism and its practical applications. Under the real-world extra-welfarism, then, health is valued in itself, no matter how differently individuals may value it in reality. Health, thus, is seen as "a physical entity of which individuals have a stock, and of which extra (gain) can be produced through the allocation of resources to health production" ${ }^{1}$ (p. 787). 
If, on one side, the focus on health solves some of the problems of using the neoclassical welfarist approach, on the other side, however, it seems to have operated a shrinking of the evaluative area. The excessive emphasis on health as the main outcome of the health care market ignores the well-being individuals obtain from non-health aspects of the use of services. In Mooney's words, the current practices of extra-welfarism do not consider the "process utility," i.e., the satisfaction that individuals obtain from the service itself, such as the readiness of assistance with low waiting time, the kindness in the care received, etc. 4 .

\section{Decisions are made upon "non-explicit" considerations on equity}

Although extra-welfarism does not break with the tradition of welfare economics, keeping the concentration on the modus operandi of maximization, the Kaldor's reasoning of Paretian welfare cannot be applied, since it is impossible to make a separation between efficiency and equity underneath this new paradigm. The distribution of resources takes place concomitantly with their production and, henceforth, it is not possible to compensate losses with the exceeding gains obtained by the winners. After all, how can we compensate someone's loss in health with the gain in health received by someone else?

Therefore, one could hastily argue that the extra-welfarist approaches do not make any appraisal of vertical equity, given that the quasi-equalitarian principle "a QALY is a QALY" assumes equal weights to all individuals, regardless of their particularities 11. Nevertheless, the focus on health maximization based on QALY or other similar indicators ended up endorsing the ethical stance that "the total sum of health produced within the health care system is what matters, no matter how that health is distributed" 1 (p. 789), and it may, as a result, perpetuate or even exacerbate inequalities in health. This becomes emblematic in the commonplace critique that QALYs are based on an interval scale, assuming the "same gain" for absolute improvements, irrespective of the initial health status (e.g., moving from 0.3 to 0.4 is equally regarded as moving from 0.8 to 0.9 ).

In Figure 2, a straight downward black line represents the social indifference curve for the standard application of QALY (or it could be any extra-welfarist health indicator), as it does not concern on the distribution of health, but solely on its maximization. However, it is likely that society members are on average inequality averse, and, thus, the appropriate social indifference curve would be the dotted black line, indicating that people are willing to lose some efficiency for mitigating inequality 12 . Now, if we consider points $h$ and $g$, they represent the same overall health gain, but it is still possible, though, that, depending on the relative characteristics of group A, society may value A more than B, so that the actual societal indifference curve is better represented by the solid grey curve.

\section{Its practices are inconsistent with Sen's notion of "inability to desire" used against welfarism}

Much of the critique on neoclassical welfarist approaches in economic evaluation in health is based on the idea developed by Sen of the "inability to desire" of individuals living in disadvantaged conditions. Nonetheless, the alternative paradigm, extra-welfarism, continues to rely on utility theory to obtain measures of non-utility outcomes. The construction of QALY, for example, involves individuals deemed as the best judges to attributing weights on different dimensions of health. In the words of Birch \& Donaldson 7 (p. 1127), "any limitations associated with the use of individual utilities as a basis for social welfare measurement would seem to have implications for using individuals' utilities as a basis for determining the weights used for EW measures of social welfare".

\section{Controversial support of empirical evidence}

There is strong evidence that people are willing to lose overall welfare in the health care sector to prioritize particular characteristics of some patients and groups, as well as to reduce inequalities in health. Here we limit ourselves to say that Coast 1, Birch \& Donaldson 7, Mooney 4, and Brouwer et al. 9 provide a monumental set of bibliographic references in this regard, although it is not rare to find studies showing different results. 
Figure 2

Societal indifference curves under different scenarios.

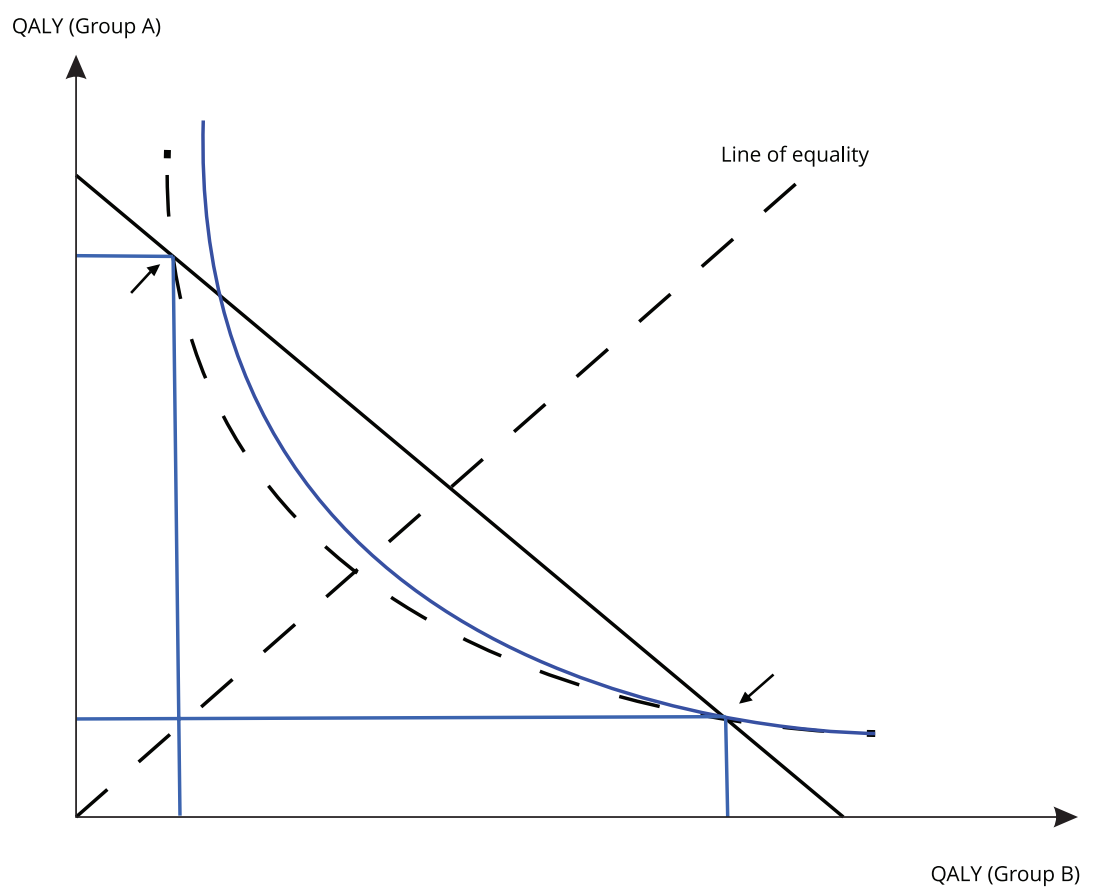

QALY: quality adjusted-life years.

Note: adapted from Norman et al. 22.

\section{Final considerations}

The debate about welfarist, extra-welfarist, and non-welfarist health economics is far from being resolved. Several innovative theoretical and practical approaches on decision-making and economic evaluation have been tested and proposed in the health sector. Some health economists, for instance, argue that PBMA (Program Budgeting and Marginal Analysis), a methodology that relies on scientific evidence and on the opinion of experts and stakeholders to conduct a marginal analysis of the possible programs and technologies to be prioritized, is the most appropriate tool for making choices of investment in the health care system 13,14,15. Others have argued that we should use the sophisticate frameworks and techniques commonly referred under the umbrella term Multi-Criteria Decision Analysis (MCDA), which normally consider a wide variety of outcomes and principles, and sometimes conflicting ones, to develop the best solutions 16,17 . There are still health economists that support the idea of communitarian claims, developed by Gavin Mooney, for whom the process of decisionmaking should base on the communitarian values of groups or the whole society 18,19,20,21. The point, though, is that there is a lot of criticism on all of them and none has seemingly risen to shadow the dominating extra-welfarist paradigm. In addition, it seems that they do not break with the tradition of welfare economics, and these new approaches can somehow be categorised within the notions of either welfarism or extra-welfarism. Overall, it is extremely important that this debate continues to be furthered. 


\section{Acknowledgments}

The author thanks Dr. Dean Regier for the thoughtful discussions on this topic and Mr. Alex Kuo for the support in developing the graphs.

\section{References}

1. Coast J. Maximisation in extra-welfarism: a critique of the current position in health economics. Soc Sci Med 2009; 69:786-92.

2. Phelps CE. 25 years of excellence: the Journal of Health Economics in retrospective. J Health Econ 2007; 26:1075-80.

3. Durkheim É. The rules of sociological methods. 8th Ed. New York: Free Press of Glencoe; 1964.

4. Mooney GH. Challenging health economics. Oxford: Oxford University Press; 2009.

5. Kaldor N. Welfare propositions of economics and interpersonal comparisons of utility. Economic Journal 1939; 49:549-52.

6. Hicks JR. The foundations of welfare economics. Economic Journal 1939; 49:696-712.

7. Birch S, Donaldson C. Valuing the benefits and costs of health care programmes: where's the "extra" in extra-welfarism? Soc Sci Med 2003; 56:1121-33.

8. Sen A. Inequality re-examined. Cambridge: Harvard University Press; 1992.

9. Brouwer WBF, Culyer AJ, van Exel NJA, Rutten FFH. Welfarism vs. extra-welfarism. J Health Econ 2008; 27:325-38.

10. Culyer A. The normative economics of health care finance and provision. In: McGuire A, Fenn P, Mayhew K, editors. Providing health care: the economics of alternative systems of finance and delivery. Oxford: Oxford University Press; 1991. p. 65-98.

11. Richardson J. Is the incorporation of equity considerations into economic evaluation really so simple? A comment on Cookson, Drummond and Weatherly. Health Econ Policy Law 2009; 4:247-54.

12. Williams A. Intergenerational equity: an exploration of the "fair innings" argument. Health Econ 1997; 6:117-32.

13. Cornelissen E, Mitton C, Davidson A, Reid C, Hole R, Visockas A-M, et al. Fit for purpose? Introducing a rational priority setting approach into a community care setting. J Health Organ Manag 2016; 30:690-710.
14. Graham JR, Mackie C. Criteria-based resource allocation: a tool to improve public health impact. J Public Health Manag Pract 2016; 22:E14-20.

15. Mitton CR, Donaldson C, Waldner H, Eagle C. The evolution of PBMA: towards a macrolevel priority setting framework for health regions. Health Care Manag Sci 2003; 6:263-9.

16. Marsh K, IJzerman M, Thokala P, Baltussen R, Boysen M, Kaló Z, et al. Multiple criteria decision analysis for health care decision making - emerging good practices: report 2 of the ISPOR MCDA Emerging Good Practices Task Force. Value Health 2016; 19:125-37.

17. Thokala P, Devlin N, Marsh K, Baltussen R, Boysen M, Kalo Z, et al. Multiple criteria decision analysis for health care decision making an introduction: report 1 of the ISPOR MCDA Emerging Good Practices Task Force. Value Health 2016; 19:1-13.

18. Jan S. Proceduralism and its role in economic evaluation and priority setting in health. Soc Sci Med 2014; 108:257-61.

19. Mooney G. "Communitarian claims" as an ethical basis for allocating health care resources. Soc Sci Med 1998; 47:1171-80.

20. Mooney G. Communitarian claims and community capabilities: furthering priority setting? Soc Sci Med 2005; 60:247-55.

21. Wiseman VL. Inclusiveness in the value base for health care resource allocation. Soc Sci Med 2014; 108:252-6.

22. Norman R, Hall J, Street D, Viney R. Efficiency and equity: a stated preference approach. Health Econ 2013; 22:568-81. 


\section{Resumo}

Há décadas se discutem as regras e os princípios para a tomada de decisões no setor de saúde. $O$ artigo apresenta uma avaliação crítica dos dois paradigmas mais importantes nessa área: welfarism $e$ extra-welfarism. O primeiro lida com a maximização da soma total das utilidades individuais como desfecho primário, enquanto o segundo concentra-se na maximização do estado geral de saúde. Argumentamos que o welfarism apresenta três problemas principais: (1) a ideia central da soma total das utilidades individuais não capta os valores da sociedade que são decisivos no contexto da saúde; (2) o uso da Potencial Melhoria de Pareto introduz uma separação irresolvível entre eficiência e equidade e (3) a utilidade individual pode não ser uma medida adequada no setor da saúde, uma vez que os indivíduos podem valorizar coisas que diminuem seu estado geral de saúde. Enquanto isso, os críticos apontam quatro limitações principais na abordagem extra-welfarist: (1) a proposta de expansão do espaço avaliativo, passando da utilidade para a saúde, na realidade pode redundar no estreitamento desse mesmo espaço; (2) a abordagem opera com considerações não explícitas de equidade; (3) ainda mantém a questão da "incapacidade de desejar" das pessoas de baixa renda que são consideradas os melhores avaliadores dos critérios utilizados para construir as medidas de saúde e (4) há controvérsias em torno das evidências empíricas sobre os valores dos membros da sociedade que sustentam as premissas. No geral, ambos os paradigmas demonstram fraquezas significativas, mas o debate continua dentro do campo da economia do bem-estar social, e mesmo as novas abordagens à alocação de recursos nos sistemas de saúde parecem ser incapazes de fugir desses limites.

Alocação de Recursos; Alocação de Recursos para a Atenção à Saúde; Economia da Saúde;

Tomada de Decisões

\section{Resumen}

Las normas y los principios para guiar la toma de decisiones en el sector de la salud se han debatido durante décadas. Presentamos una valoración crítica de los dos paradigmas más importantes a este respecto: el welfarism $y$ el extra-welfarism. Mientras que el primero se ocupa de la maximización de la suma global de las utilidades individuales como su resultado primario, este último se ha centrado en la maximización del estado general de salud. Argumentamos que el welfarism tiene tres problemas principales: (1) su idea central de la suma global de las utilidades individuales no captura los valores societales decisivamente relevantes en el contexto de la salud; (2) el uso de la Mejora Potencial de Pareto trae una separación insoluble entre la eficiencia y la equidad; $y$ (3) la utilidad individual puede no ser una buena medida en el sector de la salud, dado que las personas pueden valorar cosas que disminuyen su salud general. A su vez, el enfoque extra-welfarista es criticado con respecto a cuatro limitaciones principales: (1) la expansión del espacio evaluativo propugnada, pasando de la utilidad a la salud, puede haber representado en la realidad un estrechamiento de la misma; (2) opera con consideraciones no explicitas de equidad; (3) todavía sostiene la cuestión de la "inhabilidad de deseo" de las personas no privilegiadas que se consideran los mejores jueces de pesar los criterios usados para construir las medidas de la salud; y (4) hay evidencia empírica polémica sobre los valores de los miembros de la sociedad que apoyan sus suposiciones. En general, ambos paradigmas muestran debilidades significativas, pero el debate aún se encuentra dentro del ámbito de la economía del bienestar, e incluso los nuevos enfoques para la asignación de recursos en los sistemas de atención de salud parecen ser incapaces de escapar de estos limites.

Asignación de Recursos; Asignación de Recursos para la Atención de Salud; Economía de la Salud; Toma de Decisiones
Submitted on 31/Jan/2017

Final version resubmitted on 19/Jun/2017

Approved on 27/Jun/2017 